Perwira Journal of Economics and Business (PJEB)

E-ISSN : 2775-572X

Volume 1 Nomor 2

Agustus 2021

\title{
PENGARUH KOMPENSASI, DISIPLIN KERJA DAN MOTIVASI KERJA TERHADAP KINERJA KARYAWAN
}

\author{
Hima Barima ${ }^{1}$, Anastasia Anggarkusuma Arofah ${ }^{2}$, Endah Lestari ${ }^{3}$ \\ ${ }^{1,2,3}$ Universitas Perwira Purbalingga, Indonesia \\ himabarima@unperba.ac.id
}

\begin{abstract}
Good employee performance will directly affect the company's performance. Human resources as actors who play an active role in moving the organization to achieve its goals. The purpose of this study was to examine the effect of compensation, work discipline and work motivation on employee performance at PT. JNE Tegal City Branch. Sampling using simple random sampling and the size of the sample of 100 respondents. The results showed that compensation did not significantly influence the performance of the employees of PT. JNE Tegal City Branch, this is evidenced by the value of sig. the count is greater than 0.05, i.e. 0.604>0.05. Work discipline has a significant effect on the performance of the employees of PT. JNE Tegal City Branch, this is evidenced by the value of sig. the count is smaller than 0.05, which is $0.030<0.05$. Work motivation has a significant effect on the performance of employees of PT. JNE Tegal City Branch, this is evidenced by the value of sig. the count is smaller than 0.05, i.e. 0.046>0.05. Compensation, work discipline and work motivation have a proportion of influence on employee performance by $17.3 \%$ while the remaining $82.7 \%$ is influenced by other variables that are not in the linear regression model.
\end{abstract}

Keywords: compensation, work discipline, work motivation and employee performance

\begin{abstract}
ABSTRAK
Kinerja pegawai yang baik secara langsung akan mempengaruhi kinerja perusahaan. Sumber daya manusia sebagai aktor yang berperan aktif dalam menggerakkan organisasi dalam mencapai tujuannya. Tujuan dari penelitian ini untuk menguji pengaruh kompensasi, disiplin kerja dan motivasi kerja terhadap kinerja karyawan pada PT. JNE Cabang Kota Tegal. Pengambilan sampel menggunakan simple random sampling dan besarnya sampel sebanyak 100 responden. Hasil menunjukkan bahwa kompensasi tidak berpengaruh signifikan terhadap kinerja karyawan PT. JNE Cabang Kota Tegal, hal ini dibuktikan dengan nilai sig. hitung lebih besar dari pada nilai signifikan a. Disiplin kerja berpengaruh signifikan terhadap kinerja karyawan PT. JNE Cabang Kota Tegal, hal ini dibuktikan dengan nilai sig. hitung lebih kecil dari pada nilai signifikan a. Motivasi kerja berpengaruh signifikan terhadap kinerja karyawan PT. JNE Cabang Kota Tegal, hal ini dibuktikan dengan nilai sig. hitung lebih kecil dari pada nilai signifikan a.
\end{abstract}

Kata Kunci: kompensasi, disiplin kerja, motivasi kerja dan kinerja karyawan.

\section{PENDAHULUAN}

Kinerja memiliki arti suatu hasil kerja yang dapat dicapai oleh seseorang atau sekelompok orang dalam suatu organisasi sesuai dengan wewenang dan tanggung jawab masing-masing. Kinerja pegawai yang baik secara langsung akan mempengaruhi kinerja perusahaan. Sumber daya manusia sebagai aktor yang berperan aktif dalam menggerakkan organisasi dalam mencapai tujuannya. Tercapainya tujuan organisasi hanya dimungkinkan karena upaya para pelaku yang terdapat dalam organisasi untuk berkinerja dengan baik.Kinerja perorangan (individual performance) dengan kinerja organisasi 
(corporate performance) terdapat hubungan yang erat. Dengan perkataan lain bila Kinerja pegawai (individual performance) baik maka kemungkinan besar kinerja organisasi (corporate performance) juga baik. (Prawirosentono, 2 008).

Menurut Mathis dan Jackson (2009) kinerja pada dasarnya adalah apa yang dikerjakan dan yang tidak dikerjakan oleh karyawan. Kinerja karyawan mempengaruhi seberapa banyak mereka memberikan kontribusi kepada organisasi.

Mathis dan Jackson (2009) lebih lanjut memberikan standar kinerja sesorang yang dilihat kuantitas output, kualitas output, jangka waktu output, kehadiran di tempat kerja dan sikap kooperatif. Standar kinerja tersebut ditetapkan berdasarkan kriteria pekerjaan yaitu menjelaskan apaapa saja yang sudah diberikan organisasi untuk dikerjakan oleh karyawannya, oleh karena itu kinerja individual dalam kriteria pekerjaan haruslah diukur, dibandingkan dengan standar yang ada dan hasilnya harus dikomunikasikan kepada seluruh karyawan. Mathis dan Jackson (2009) juga menjelaskan standar kinerja dapat berupa output produksi atau lebih dikenal dengan standar kinerja numerik dan standar kinerja non numerik.

Dalam peningkatan kinerja, terdapat kompensasi yang mempengaruhi dari kinerja karyawan. Kompensasi merupakan salah satu strategi manajemen sumber daya manusia untuk menciptakan keselarasan kerja antara karyawan dengan pimpinan perusahaan dalam mencapai tujuan dan sasaran yang sudah ditetapkan. Kompensasi merupakan istilah luas yang berkaitan dengan imbalan imbalan finansial (financial reward) yang diterima oleh orang-orang melalui hubungan kepegawaian mereka dengan sebuah perusahaan (Simamora:2004).

Kompensasi yang diberikan secara benar akan berpengaruh pada para pegawai lebih terpuaskan dan termotivasi untuk mencapai sasaran-sasaran organisasi.
Menurut Hasibuan (2013) kompensasi kerja adalah semua pendapatan yang berbentuk uang, barang langsung atau tidak langsung yang diterima karyawan sebagai imbalan balas jasa yang diberikan kepada perusahaan.kompensasi merupakan fungsi strategi sumber daya manusia yang mempunyai imbas signifikan atas fungsifungsi sumber daya manusia lainnya. Kompensasi kerja sangat berpengaruh terhadap kinerja pegawai, jika sebuah kinerja itu dihargai dengan sebuah kompensasi maka kepuasan pegawai akan tercapai.

Disiplin kerja dapat dilihat sebagai sesuatu yang besar manfaatnya, baik bagi kepentingan organisasi maupun bagi pegawainya. Bagi organisasi adanya disiplin kerja akan menjamin terpeliharanya tata tertib dan kelancaran pelaksanaan tugas, sehingga di peroleh hasil yang optimal. Adapun bagi pegawai akan diperoleh suasana kerja yang menyenangkan sehingga akan menambah semangat kerja dalam melaksanakan pekerjaannya.

Selain kompensasi dan disiplin kerja, perusahaan juga harus memperhatikan mengenai bagaimana menjaga dan mengelola motivasi pegawai dalam bekerja agar selalu tinggi dan fokus pada tujuan perusahaan (Faizal et al., 2019). Menjaga motivasi karyawaan itu sangatlah penting karena motivasi itu adalah motor penggerak bagi setiap individu yang mendasari mereka untuk bertindak dan melakukan sesuatu. Orang tidak akan melakukan sesuatu hal secara optimal apabila tidak mempunyai motivasi yang tinggi dari dalam dirinya sendiri untuk melalukan hal tersebut (Sulaeman, 2016)

Robin dan Judge (2008:222), mendefinisikan motivasi sebagai suatu proses yang menjelaskan intensitas, arah dan ketekunan seorang individu untuk mencapai tujuannya. Dari definisi tersebut dapat dicermati bahwa motivasi menjadi bagian yang sangat penting yang mendasari individu atau seseorang dalam melakukan 
sesuatu atau mencapai tujuan tertentu yang diinginkan.

Karena persaingan dipasar domestic, JNE juga memusatkan memperluas jaringan domestic.Dengan jaringan domestiknya Tiki dan namanya, JNE mendapat keuntungan persaingan dalam pasar domestic.JNE juga memperluas pelayanannya dengan logistic dan distribusi.Selama bertahun-tahun Tiki dan JNE berkembang dan menjadi dua perusahaan yang punya arah masingmasing.Karena ini kedua perusahaan tersebut menjadi saingan.Akhirnya JNE menjadi perusahaan mandiri dengan manajemen sendiri.JNE membuat logo sendiri yang membedakan dengan TIiki.JNE membeli gedung sendiri pada tahun 2002 dan mendirikan JNE Operations Sorting Center.Kemudian pada tahun 2004 JNE membeli gedung yang dijadikan Kantor Pusat.Keduanya berada di Jakarta.

JNE memiliki 400 Cabang dan 4500 agen yang dibawahi oleh cabang tersebut. Dalam penelitian ini cabang yang akan di teliti berada di Kota Tegal, Jawa Tengah.

Kehadiran setiap bulannya di Kantor Cabang JNE Kota Tegal mengalami penurunan di beberapa tingkatan jabatan, hal ini dimungkinkan ada beberapa karyawan yang merasa belum sesuai antara waktu kerja tambahan dengan kompensasi yang diberikan oleh pihak perusahaan.

Jumlah karyawan PT. JNE Kota Tegal mengalami penurunan di setiap tahunnya, hal ini dikarenakan antara waktu tambahan kerja atau lembur tidak sesuai dengan kompensasi yang diberikan oleh karyawan dan pekerjaan tersebut sering menimbulkan stres kerja bagi karyawan yang diakibatkan tambahan jam kerja setiap harinya.

\section{METODE PENELITIAN}

\section{Populasi}

Jumlah populasi dalam penelitian ini sebesar 115 orang yaitu karyawan PT. JNE Kota Tegal.

\section{Sampel}

Pengambilan sampel dilakukan dengan metode Stratified Random Sampling (pengambilan sampel random distratifikasi).

Jumlah karyawan tetap sebanyak 115 orang.Untuk menentukan jumlah responden, maka digunakan Stratified Random Sampling, pengambilan sampel menggunakan metode tersebut dikarenakan mengambil responden berdasarkan kemudahan yang diperoleh dalam pengambilan sampel responden.

Ukuran sampel ditentukan dengan rumus Slovin (Sugiono, 2010), sebagai berikut :

$$
n=\frac{N}{1+N \cdot e^{2}}
$$

Dari jumlah populasi yang ada, dengan tingkat kelonggaran ketidaktelitian sebesar 5\%, maka dengan menggunakan rumus Slovin diperoleh jumlah sampel $\begin{array}{llll}\text { sebesar } & 89 & \text { atau } & 100\end{array}$ responden.Pengambilan jumlah sampel 100 di karenakan untuk mengantisipasi responden yang tidak mengembalikan kuesioner.

\section{Definisi Operasional}

\begin{tabular}{|c|l|l|}
\hline Variabel & \multicolumn{1}{|c|}{$\begin{array}{c}\text { Definisi } \\
\text { Operasional }\end{array}$} & \multicolumn{1}{|c|}{ Indikator } \\
\hline Kompensasi & Hasibuan & a) Gaji \\
& $(2006: 118)$ & b) Insentif \\
Kompensasi & c) Bonus \\
& adalah semua & d) Pelatihan \\
dan & pendapatan yang & dan \\
& berbentuk uang, & penga \\
& barang langsung & ngan \\
& atau tidak & e) Pujian \\
& langsung yang & f) Cuti \\
& diterima & \\
& karyawan & \\
& sebagai imbalan & \\
& atas jasa yang & \\
diberikan & \\
& karyawan. & \\
& Variabel & \\
& kompensasi & \\
diukur dengan & \\
& menggunakan & \\
indikator & \\
\hline
\end{tabular}




\begin{tabular}{|c|c|c|}
\hline & $\begin{array}{l}\text { sebagai berikut } \\
\text { (Samsudin, } \\
\text { 2006): }\end{array}$ & \\
\hline $\begin{array}{l}\text { Disiplin } \\
\text { Kerja }\end{array}$ & $\begin{array}{l}\text { Menurut } \\
\text { Sinambela } \\
(2012 \text { : 239), } \\
\text { "disiplin kerja } \\
\text { merupakan } \\
\text { kemampuan } \\
\text { kerja seseorang } \\
\text { untuk secara } \\
\text { teratur, tekun } \\
\text { terus menerus } \\
\text { dan bekerja } \\
\text { sesuai dengan } \\
\text { aturan-aturan } \\
\text { berlaku dengan } \\
\text { tidak melanggar } \\
\text { aturan-aturan } \\
\text { yang sudah } \\
\text { ditetapkan" }\end{array}$ & $\begin{array}{l}\text { a) Kehadiran } \\
\text {; } \\
\text { b) Ketepatan } \\
\text { waktu; } \\
\text { c) Menaati } \\
\text { instruksi } \\
\text { kerja } \\
\text { pengawas; } \\
\text { d) Ketaatan } \\
\text { terhadap } \\
\text { aturan } \\
\text { kantor; } \\
\text { e) Pegawai } \\
\text { menghasil } \\
\text { kan jumlah } \\
\text { pekerjaan } \\
\text { yang } \\
\text { memuaska } \\
\text { n; } \\
\text { f) Pegawai } \\
\text { memakai } \\
\text { seragam } \\
\text { kantor. }\end{array}$ \\
\hline $\begin{array}{l}\text { Motovasi } \\
\text { Kerja }\end{array}$ & $\begin{array}{l}\text { Motivasi } \\
\text { merupakan } \\
\text { keadaan dalam } \\
\text { pribadi } \\
\text { seseorang yang } \\
\text { mendorong } \\
\text { keinginan } \\
\text { individu untuk } \\
\text { melakukan } \\
\text { kegiatan- } \\
\text { kegiatan tertentu } \\
\text { guna mencapai } \\
\text { tujuan" } \\
\text { (Handoko, 2003: } \\
\text { 252) }\end{array}$ & $\begin{array}{l}\text { a) Kebutuhan } \\
\text { fisiologis; } \\
\text { b) Kebutuhan } \\
\text { rasa aman; } \\
\text { c) Kebutuhan } \\
\text { untuk rasa } \\
\text { memiliki; } \\
\text { d) Kebutuhan } \\
\text { akan harga } \\
\text { diri; } \\
\text { e) Kebutuhan } \\
\text { untuk } \\
\text { mengaktua } \\
\text { lisasi diri. }\end{array}$ \\
\hline $\begin{array}{l}\text { Kinerja } \\
\text { Karyawan }\end{array}$ & $\begin{array}{l}\text { Ukuran-ukuran } \\
\text { dijadikan tolok } \\
\text { ukur dalam } \\
\text { menilai kinerja. } \\
\text { Dimensi atau } \\
\text { ukuran kinerja } \\
\text { sangat } \\
\text { diperlukan } \\
\text { karena akan } \\
\text { bermanfaat baik } \\
\text { bagi para pihak" } \\
\text { (Sudarmanto, } \\
\text { 2009: 11) }\end{array}$ & $\begin{array}{l}\text { a) Hasil } \\
\text { kerja; } \\
\text { b) Perilaku } \\
\text { kerja; } \\
\text { c) Sifat } \\
\text { pribadi } \\
\text { yang ada } \\
\text { hubungan } \\
\text { nya } \\
\text { dengan } \\
\text { pekerjaan. }\end{array}$ \\
\hline
\end{tabular}

\section{Metode Pengumpulan Data}

Pengumpulan data dengan menggunakan daftar pertanyaan yang disediakan untuk menjawab pertanyaan secara tertulis oleh responden. Kuisioner berisi pertanyaan, setiap pertanyaan dibuka peluang kemungkinan lima jawaban. Dari lima jawaban tersebut, responden diharapkan memilih satu jawaban yang dianggap paling sesuai dengan dirinya. Dengan menggunakan skala Linkert (Sugiyono, 2010) masing-masing jawaban mempunyai nilai skor, dimana 1 sangat tidak setuju sampai dengan 5 sangat setuju.

\section{Analisis Data}

Analisis data dilakukan dengan Analisis Regresi Linier Berganda menggunakan program SPSS.

\section{HASIL DAN PEMBAHASAN}

Uji Validitas

\begin{tabular}{|c|c|c|c|}
\hline Variabel/Item & r Hitung & $\begin{array}{c}\text { R Tabel } \\
\text { (One } \\
\text { Tale) }\end{array}$ & $\begin{array}{l}\text { Valid / } \\
\text { Tidak }\end{array}$ \\
\hline \multicolumn{4}{|c|}{ Variabel Kompensasi } \\
\hline $\mathrm{X} 1.1$ & 0,578 & 0,1996 & Valid \\
\hline $\mathrm{X} 1.2$ & 0,830 & 0,1996 & Valid \\
\hline $\mathrm{X} 1.3$ & 0,880 & 0,1996 & Valid \\
\hline $\mathrm{X} 1.4$ & 0,814 & 0,1996 & Valid \\
\hline $\mathrm{X} 1.5$ & 0,819 & 0,1996 & Valid \\
\hline $\mathrm{X} 1.6$ & 0,774 & 0,1996 & Valid \\
\hline \multicolumn{4}{|c|}{ Variabel Disiplin Kerja } \\
\hline $\mathrm{X} 2.1$ & 0,723 & 0,1996 & Valid \\
\hline $\mathrm{X} 2.2$ & 0,657 & 0,1996 & Valid \\
\hline $\mathrm{X} 2.3$ & 0,758 & 0,1996 & Valid \\
\hline $\mathrm{X} 2.4$ & 0,770 & 0,1996 & Valid \\
\hline $\mathrm{X} 2.5$ & 0,787 & 0,1996 & Valid \\
\hline $\mathrm{X} 2.6$ & 0,716 & 0,1996 & Valid \\
\hline \multicolumn{4}{|c|}{ Variabel Motivasi Kerja } \\
\hline $\mathrm{X} 3.1$ & 0,821 & 0,1996 & Valid \\
\hline $\mathrm{X} 3.2$ & 0,785 & 0,1996 & Valid \\
\hline X3.3 & 0,826 & 0,1996 & Valid \\
\hline X3.4 & 0,734 & 0,1996 & Valid \\
\hline $\mathrm{X} 3.5$ & 0,820 & 0,1996 & Valid \\
\hline \multicolumn{4}{|c|}{ Variabel Kinerja Karyawan } \\
\hline Y1.1 & 0,826 & 0,1996 & Valid \\
\hline Y1.2 & 0,863 & 0,1996 & Valid \\
\hline Y1.3 & 0,832 & 0,1996 & Valid \\
\hline
\end{tabular}

Dari hasil uji diatas, semua indikator pertanyaan dikatakan valid sehingga pengujian dapat dilanjutkan ketahap berikutnya. 


\section{Uji Reliabilitas}

\begin{tabular}{ccc} 
Variabel & $\begin{array}{c}\text { Nilai } \\
\text { Cronbach's } \\
\text { Alpha } \\
\text { Based } \text { on } \\
\text { Standardized } \\
\text { Item }\end{array}$ & Keterangan \\
X1.1 & 0,945 & Reliabel \\
X1.2 & 0,940 & Reliabel \\
X1.3 & 0,940 & Reliabel \\
X1.4 & 0,941 & Reliabel \\
X1.5 & 0,941 & Reliabel \\
X1.6 & 0,943 & Reliabel \\
X2.1 & 0,940 & Reliabel \\
X2.2 & 0,942 & Reliabel \\
X2.3 & 0,942 & Reliabel \\
X2.4 & 0,942 & Reliabel \\
X2.5 & 0,942 & Reliabel \\
X2.6 & 0,942 & Reliabel \\
X3.1 & 0,939 & Reliabel \\
X3.2 & 0,940 & Reliabel \\
X3.3 & 0,940 & Reliabel \\
X3.4 & 0,942 & Reliabel \\
X3.5 & 0,940 & Reliabel \\
Y1.1 & 0,940 & Reliabel \\
Y1.2 & 0,941 & Reliabel \\
Y1.3 & 0,943 & Reliabel \\
\hline
\end{tabular}

Dari analisis tersebut, nilai alpha cronbach's sudah diatas 0,600 , artinya kuesioner sudah reliabel karena lebih besar dari 0,600 .

\section{Uji Normalitas}

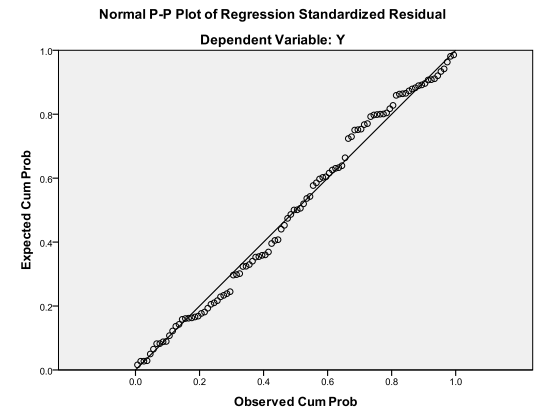

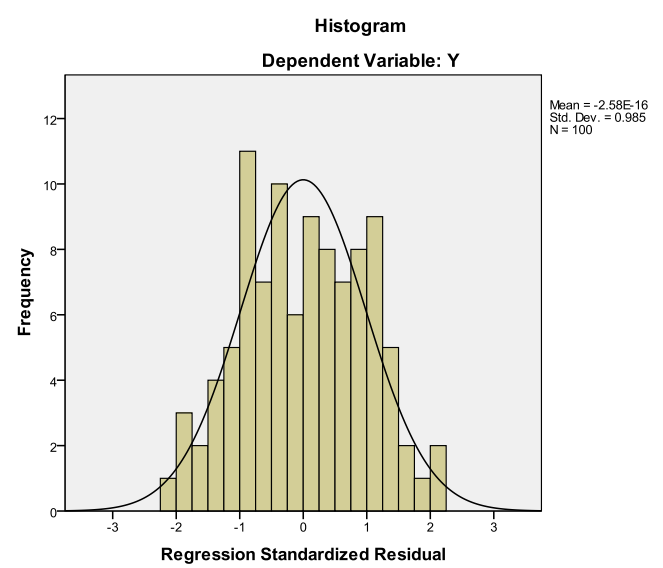

Pada gambar dapat dilihat bahwa grafik normal probability plot menunjukkan pola grafik yang normal.Hal ini terlihat dari titik yang menyebar disekitar grafik normal.Hal ini terlihat dari titik-titik yang menyebar disekitar garisdiagonal dan penyebarannya mengikuti garis diagonal.Oleh karena ini dapat disimpulkan bahwa model regresi layak diapaki karena memenuhi asumsi normalitas.

\section{Uji Multikolinieritas}

\begin{tabular}{|rr|r|r|r|}
\hline \multicolumn{2}{|l|}{ Model } & \multicolumn{2}{|c|}{ Collinearity Statistics } \\
\cline { 3 - 5 } & & Sig. & Tolerance & \multicolumn{1}{c|}{ VIF } \\
\hline 1 & (Con & .002 & & \\
stant & & & \\
) & & & \\
& & & \\
& X1 & .604 & .494 & 2.025 \\
X2 & .030 & .485 & 2.063 \\
X3 & .046 & .666 & 1.502 \\
\hline
\end{tabular}

a. Dependent Variable: $Y$

Dilihat dari tabel diatas dapat diketahui nilai VIF semua variabel tidak lebih besar dari 10 artinya tidak terjadi gejala multikolineritas. 


\section{Uji Heterokedastisitas}

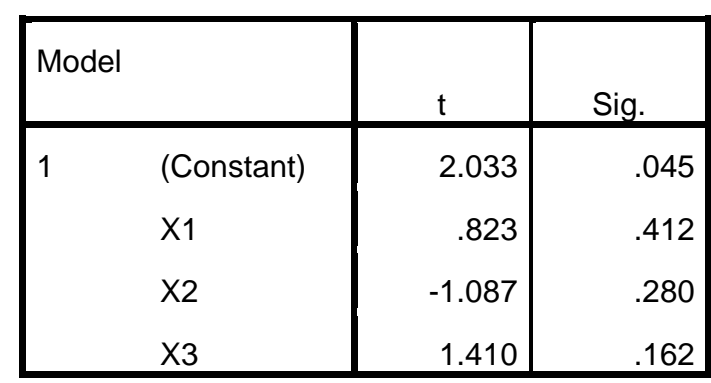

a. Dependent Variable: ABRESID

Dari tabel diatas, nilai probabilitasnya sidah lebih besar dari nilai alphanya $(0,05)$, sehingga dalam model penelitian ini tidak mengandung unsure heterokedastisitas.

\section{Uji F}

\begin{tabular}{|l|r|r|r|}
\hline Model & df & F & Sig. \\
\hline 1 Regression & 3 & 6.675 & $.000^{\mathrm{a}}$ \\
Residual & 96 & & \\
Total & 99 & & \\
\hline
\end{tabular}

a. Predictors: (Constant), X3, X1, X2

b. Dependent Variable: $Y$

Dari hasil uji $\mathrm{F}$ pada penelitian ini didapatkan nilai $\mathrm{F}$ hitung sebesar 6,675 dengan angka signifikansi ( $\mathrm{P}$ value) sebesar 0,000 . Dengan tingkat signifikansi $95 \%(\alpha$ $=0,05)$. Angka signifikansi ( $\mathrm{P}$ value $)$ sebesar $0,000<0,05$. Atau dengan melihat dari nilai F, syarat diterima jika F Hitung > dari F Tabel. Dapat dilihat bahwa dalam perhitungan nilai $\mathrm{F}$ Hitung sebesar 6,675 dan nilai $F$ Tabel sebesar 2,699 yang artinya F Hitung > dari F Tabel atau 6,675> 2,699.Atas dasar perbandingan tersebut, maka H0 ditolak atau berarti variabel kompensasi, disiplin kerja dan motivasi kerja mempunyai pengaruh yang signifikan secara bersama-sama terhadap variabel kinerja karyawan.

\section{Uji Regresi Linier Berganda}

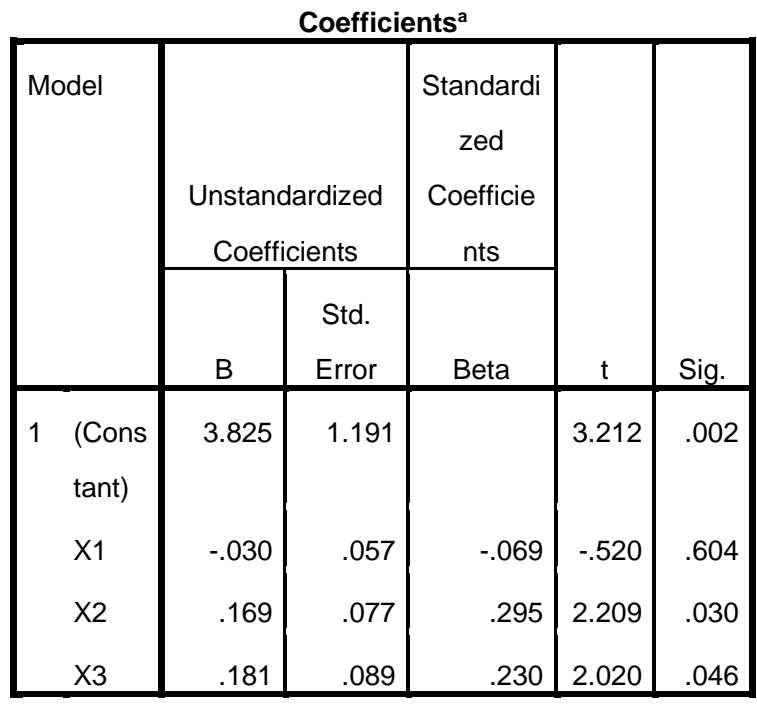

a. Dependent Variable: $Y$

Berdasarkan pada tabel diatas maka didapatkan persamaan regresi linier berganda sebagai berikut:

$Y=3,825-0,030 \times 1+0,169 \times 2+0,181 \times 3$

\section{Pembahasan}

Kompensasi berpengaruh signifikan terhadap kinerja karyawan.

Pernyataan hipotesis pertama bahwa kompensasi berpengaruh siginifikan terhadap kinerja karyawan tidak terbukti. Hal ini dapat ditunjukkan dengan nilai signifikansi (P Value) sebesar 0,604 yang lebih besar dari 0,05 serta nilai koefisien regresi sebesar -0,069. Dapat disimpulkan bahwa semakin tinggi kompensasi, maka tidak akan semakin tinggi kinerja karyawan. Hal ini dikarenakan pekerja merasa pekerjaan mereka yang tidak sesuai dengan dikerjakan oleh para karyawan walau diberikan kompensasi yang sesuai dengan minimal upah minimum di suatu daerah sehingga akan menurunkan tingkat dari kinerja. Selain itu terkadang karyawan yang bekerja lembur tidak dihitung kompensasi lembur sehingga menurunkan tingkat kinerja karyawan.

H2: Disiplin Kerja berpengaruh signifikanterhadap kinerja karyawan.

Pernyataan hipotesis kedua bahwa disiplin kerja berpengaruh siginifikan terhadap kinerja karyawan terbukti. Hal ini dapat 
ditunjukkan dengan nilai signifikansi ( $\mathrm{P}$ Value) sebesar 0,030 yang lebih kecil dari 0,05 serta nilai koefisien regresi sebesar 0,295 . Dapat disimpulkan bahwa semakin tinggi disiplin kerja, maka akan semakin tinggi kinerja karyawan. Hal ini dikarenakan pekerja memiliki rasa tanggung jawab terhadap pekerjaan yang mereka terima dan memiliki disiplin terhadap pekerjaan yang mereka kerjakan dan saat mereka telah menyelesaikan pekerjaan mereka sesuai dengan waktu bahkan sebelum batas waktu yang ditentukan maka karyawan mendapatkan reward dari perusahaan sehingga akan meningkatkan kinerja.

\section{H3: Motivasi Kerja berpengaruh signifikan terhadap kinerja karyawan.}

Pernyataan hipotesis ketiga bahwa motivasi kerja berpengaruh siginifikan terhadap kinerja karyawan terbukti. Hal ini dapat ditunjukkan dengan nilai signifikansi ( $P$ Value) sebesar 0,046 yang lebih kecil dari 0,05 serta nilai koefisien regresi sebesar 0,230. Dapat disimpulkan bahwa semakin tinggi motivasi kerja, maka akan semakin tinggi kinerja karyawan. Hal ini dikarenakan pekerja merasa memiliki tujuan dalam bekerja sehingga mereka termotivasi untuk bekerja lebih giat sehingga dapat meningkatkan kinerja.Selain itu, karyawan termotivasi dalam bekerja lebih giat karena adanya keluarga.Kemudian memiliki pemimpin yang bijaksana, mengayomi dan selalu memberikan motivasi kepada karyawan sehingga meningkatkan kinerja karyawan.

\section{Koefisien Determinasi $\left(\mathbf{R}^{2}\right)$} Model Summary

\begin{tabular}{|l|r|r|r|}
\hline Model & $\mathrm{R}$ & $\mathrm{R}$ Square & $\begin{array}{c}\text { Adjusted R } \\
\text { Square }\end{array}$ \\
\hline 1 & $.415^{\mathrm{a}}$ & .173 & .147 \\
\hline
\end{tabular}

a. Predictors: (Constant), X3, X1, X2

Jika dilihat dari nilai R-Square yang besarnya 0,173 menunjukkan bahwa proporsi pengaruh variabel kompensasi, disiplin kerja dan motivasi kerja terhadap variabel kinerja karyawan sebesar $17,3 \%$. Artinya, Kompensasi, disiplin kerja dan motivasi kerja memiliki proporsi pengaruh terhadap kinerja karyawan sebesar 17,3\% sedangkan sisanya $82,7 \%(100 \%-17,3 \%)$ dipengaruhi oleh variabel lain yang tidak ada didalam model regresi linier.

\section{SIMPULAN}

Berdasarkan hasil penelitian dan pembahasan diatas, maka dalam penelitian ini dapat disimpulkan kompensasi tidak berpengaruh signifikan terhadap kinerja karyawan hal ini dikarenakan pekerja loyal kepada perusahaan dimana karyawan memiliki tujuan dalam bekerja. Disiplin Kerja berpengaruh signifikan terhadap kinerja karyawan hal ini dikarenakan secara tidak langusng karena budaya organisasi, karyawan memiliki disiplin dalam bekerja. Motivasi Kerja berpengaruh signifikan terhadap kinerja karyawan hal ini dikarenakan karyawan secara pribadi memiliki tujuan dalam bekerja sehingga hal tersebut yang menaikkan motivasi kerja.

\section{REFERENSI}

Ahirudin. (2011). Pengaruh Konflik Kerja dan Stres Kerja Terhadap Kinerja Karyawan CV. Bina

Anoraga, Panji. (2001). Psikologi Kerja. Jakarta. Jakarta: PT Rineka Cipta.

Anoraga, Panji. (2003). Manajemen Organisasi.PT. Gramedia Pustaka Umum Jakarta.

Andini, Yossi Tri. (2005). Faktor-faktor Penyebab Stres Kerja Pada Pegawai Negeri Sipil Pasar

Atosokhi, Antonius. (2002). Character Building I : Relasi Dengan Diri Sendiri. PT. Gramedia Pustaka Utama Umum Jakarta.

As'ad, Moh. (1987). Psikologi Industri Edisi Ke-3. Jakarta: Liberti. 
Ashar Sunyoto, Munandar. (2001). Psikologi Industri dan Organisasi. Jakarta: UI Press.

Faizal, R., Sulaeman, M., \& Yulizar, I. (2019). Pengaruh Budaya, Motivasi Kerja Dan Kompetensi Terhadap Kinerja Karyawan. EBA Journal: Journal Economics, Bussines and Accounting, 5(1), 11-21. https://doi.org/10.32492/eba.v5i1.706

Sulaeman, M. (2016). Pengaruh Penerapan Nilai-Nilai Islam Dan Komitmen Terhadap Etos Kerja Dan Dampaknya Kepada Kualitas Sumber Daya Manusia Di Lingkungan Pemerintah Kabupaten Tasikmalaya. Jurnal Ekonomi \& Studi Pembangunan, $17(2)$. https://doi.org/10.18196/jesp.17.2.378 8

Gibson, Ivancevich. (1987). Organisasi: Proses Struktur Perilaku. Edisi Lima, Jakarta: Erlangga.

Ghozali, Imam. (2009). Ekonometrika Teori, Konsep dan Aplikasi dengan SPSS 17. BadanPenerbit Universitas Diponegoro: Semarang.

Ghozali, imam. (2011). Aplikasi analisis multivariate dengan program IBM SPSS 19. BadanPenerbit Universitas Diponegoro: Semarang.

Campell. D. T. \& Fiske. D. w. (1959).Convergent and discriminant validation by themultitra itmultimethod matrix.Phychological bulletin. 56. 81-105.

Cipta. Nusa Perkasa Bandar Lampung. Jurnal Organisasi dan Manajemen.Vol.I,No:1.

Dharmmesta, B.S. (1999). Loyalitas Pelanggan: Sebuah Kajian Konseptual. Sebagai Panduan Bagi Peneliti.Jurnal Ekonomi dan Bisnis. Indonesia, Vol. 14, No. 3.

Dwi Sihono Raharjo.(2005). Kinerja Karywan Survei di Bank Negara Indonesia dan Bank Central Asia. Jurnal Manajemen, Th IX/01/Feb/2005, Hal 19-26. 60.

Homburg, C. dan Giering, A. 2001.Personal Characteristics as Moderators of the Relationship Between Customer Satisfaction and Loyalty-anEmpirical

Analysis.Psychology \& Marketing, Vol 18 (1).

Hon, Alice H. Y. (2013). "The Effects of Group Conflict and Work Stres on EmployeePeformances"..Journal Tourism Management.

Lies Indriyatni. (2010). Pengaruh Konflik Terhadap Kinerja Organisasi Atau Perusahaan.Jurnal Fokus Ekonomi. Vol. V. No.1.

Paul S. Bush, and Michael J. Houston. 1985. Marketing: StrategicFoundation. Illinois : Homewood.

Rempel, J.K., Holmes, J.G., \& Zanna, M.P. 1985. Trust In Close Relationships.Journal of Personality and Social Psychology Vol. 49 No. 1. 